\title{
Travel characteristics of suburban residents during the COVID- 19 pandemic (case study of Sonosewu, Bantul Regency)
}

\author{
Dewina Inggar Santi ${ }^{1}$, and Sri Rum Giyarsih ${ }^{1 *}$ \\ ${ }^{1}$ Department of Environmental Geography, Faculty of Geography, Gadjah Mada University, Yogyakarta, 55281, Indonesia
}

\begin{abstract}
The existence of COVID-19 pandemic had an impact on residents' travel, including in Sonosewu Hamlet, Bantul Regency, Indonesia because the government has implemented recommendation to reduce residents' mobility in order to accelerate the handling of COVID-19. This research is interesting because there was no research that specifically examines the characteristics of residents' travel during COVID-19 pandemic in the suburbs of Yogyakarta. The purpose of this study was to identify the travel characteristics of the residents of Sonosewu during the COVID-19 pandemic. The data collection was carried out through questionnaire surveys. The data processing and analysis were carried out by using descriptive statistical methods. Based on the results obtained from 328 respondents, it is known that the travel frequency from November 30 to December 6, 2020, tended to be high with 6 to 7 trips a week. The purpose of travel was mostly to work and shopping, and the main travel destinations are Bantul Regency and Yogyakarta City. The result of this research will be useful for the development of knowledge, especially in the field of urban geography and can be taken into consideration by the government for the development of suburban areas.
\end{abstract}

\section{Introduction}

Suburban area has several characteristics, such as its location directly adjacent to the city area, the population is oriented towards the city, the rural area where residents work in the city, and the residents need life both in the city and in the village [1]. Based on the characteristics, residents will do travel. Population travel is defined as a one-way movement from the point of origin to the destination using certain modes of transportation [2]. According to Meyer and Miller, it can be seen from some attributes, such as purpose and frequency [3].

Sonosewu Hamlet, Ngestiharjo Village, Kasihan Subdistrict, Bantul Regency is one of the suburban areas because it is directly adjacent to the city of Yogyakarta (Figure 1). This is beneficial for the residents of Sonosewu because there are options for socio-economic facilities to meet the needs of life both in the surrounding area and in the city of Yogyakarta so that the opportunity to travel is even higher. However, this does not always apply in all conditions, especially during the COVID-19 pandemic.

The COVID-19 pandemic is caused by the Severe Acute Respiratory Syndrome Coronavirus-2 (SARSCoV-2) virus which attacks the respiratory tract and is a dangerous infectious disease where transmission comes from human-to-human transmission through droplets, either directly or indirectly [4]. Romdiati revealed that population travel as the cause of the spread of the virus was evidenced at the beginning of this virus spreading to residents who traveled internationally, then spreading to local transmission [5]. This shows that travel and direct social interactions will exacerbate the spread of COVID-19. Therefore, the government issued several policies and appeals in order to prevent the wider spread of the virus and accelerate the handling of the COVID19 pandemic.

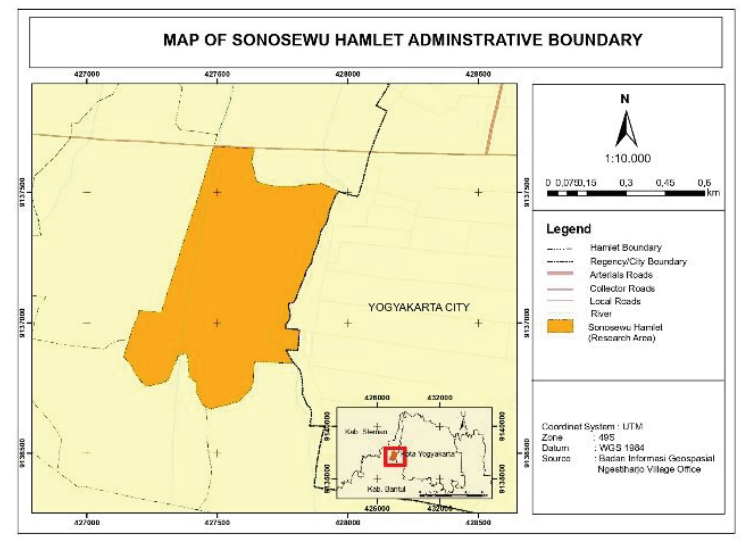

Fig. 1. Map of Sonosewu Hamlet administrative boundary.

Kasihan Subdistrict during the COVID-19 pandemic by the Bantul Regency Health Office was classified as a moderate risk zone with a value of 2.0 or level 3 with the criteria that the area had a high risk of spreading COVID-19, and the spread and potential of the virus were out of control [6]. Based on this condition, the Bantul Regency Government has implemented several sector implementations in this zone, including advising people to stay at home, temporarily closing educational facilities, carrying out social and physical distancing, and so on [7]. With these policies, it is hoped that

\footnotetext{
*Corresponding author: srirum@ugm.ac.id
} 
residents can reduce social activities and change their travel behavior.

Changes in population activity during the pandemic, one of which is indicated by the results of the identification of movements by Google COVID-19 Community Mobility Reports [8]. As of June 27, 2020, there was still a decrease in the movement to several places despite the stipulation of a new adaptation period in the Special Region of Yogyakarta (Figure 2). The movement to several places is still decreasing compared to the baseline of measurement, namely the median value from January 3 to February 6, 2020. Also, data from the Office for the Coordination of Humanitarian Affairs shows that there was a decrease in the average daily movement in Bantul Regency from March 12020 to July 5 at $-23.1 \%$ [9].

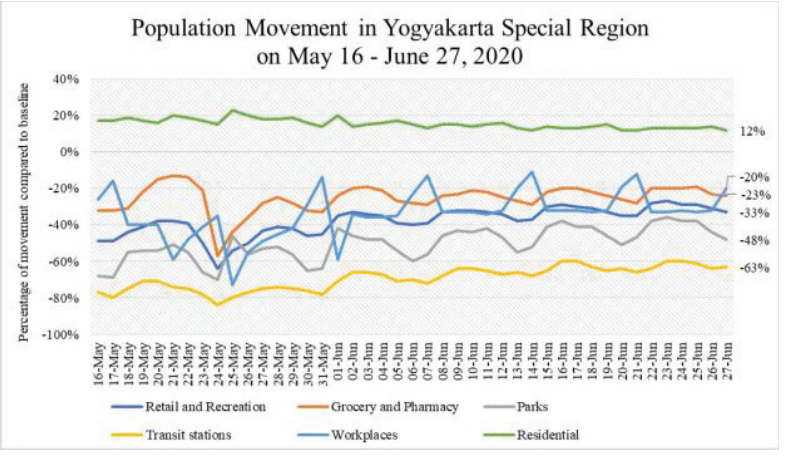

Fig. 2. Population movement in Yogyakarta Special Region to various places compared to the basic measurement. Source: Google COVID-19 Community Mobility Report.

Based on research problems, this study aims to identify the travel characteristics of the Sonosewu population during the COVID-19 pandemic in terms of frequency and purpose. This research can be used as a source of information regarding the frequency of trips made by residents for one week during the pandemic, and the purpose of these trips can be known as a matter of consideration for the government in determining policies during the COVID-19 pandemic. In addition, the results of this research will also be useful for the development of knowledge, especially in the field of urban geography.

\section{Research method}

The population in this study were Sonosewu residents with an age range of 18 to 56 years old. The consideration of this age group is related to the range of productive age. Residents aged 18 years old are assumed to be able to travel independently supported by possession of a driver's license, while 56 years old is the limit before retirement age and in this group, most of them constitute the workforce.

The sampling technique used probability sampling, that is, each research unit from the population has the same opportunity to be used as a sample [10]. The process of determining the sample used the simple random sampling method, where samples are taken from the population randomly without paying attention to the strata [10]. This is because all populations are homogeneous in terms of being affected by the COVID-
19 pandemic and subject to policies and appeals related to restrictions on social activities, travel restrictions, and physical distancing. The determination of the number of samples was based on calculations in the Issac and Michael formula with an error rate of 5\% [10]. Based on the calculation of 2,244 population members, the number of respondents was 328 people.

The overall data used in this study are primary data obtained by using a systematic and written questionnaire to the respondents. The use of a questionnaire is more efficient if the researcher knows the variables to be measured and is more suitable if the number of respondents is large enough [10]. This is in line with this study because the number of respondents is quite large. The data collection process was carried out by distributing questionnaires to respondents to obtain data on the travel characteristics for one week, namely from November 30 to December 6, 2020. Data processing and analysis were carried out using descriptive statistical techniques. Data analysis was carried out to describe the travel characteristics of the population in terms of frequency, destination, and distribution of destination locations during the COVID-19 pandemic.

\section{Results and discussion}

Coronavirus disease or COVID-19 is an infectious disease caused by the Severe Acute Respiratory Syndrome Coronavirus-2 (SARS-CoV-2) virus which first emerged in December 2019 in Wuhan, China [4]. Until now, COVID-19 has become a pandemic that has hit many countries around the world, including Indonesia. The first recorded case of COVID-19 in Indonesia was reported on March 2, 2020, with two positive cases [11]. The spread and transmission of COVID-19 are fast and widespread between humans, increasing the number of confirmed cases.

The COVID-19 pandemic has an impact on almost all sectors of life, including education, economy, and even has an impact on travel behavior. The object identified in this study was a home-based trip, where the home trip is the beginning of the activity and will eventually return home [2]. This study was represented by a sample of 328 respondents with details of 163 males and 165 females who were identified during one week during the COVID-19 pandemic from November 30 to December 6, 2020. It was recorded that there were 1,335 trips.

\subsection{Travel frequency}

Travel frequency is the number of trips in time units. The time used in this study was one week during the COVID-19 pandemic. This parameter is most highlighted because the government has appealed to limit activities outside the home or to reduce the number of trips in the context of efforts to accelerate the handling of COVID-19. Population mobility is correlated with the growth rate of COVID-19 cases, where a decrease in population travel has a significant positive relationship with reduce case growth of COVID-19 [12]. De Vos revealed that the existence of 
several policies during the COVID-19 pandemic allowed the frequency of travel for the population to be less because many had worked from home, and some outside activities decreased in frequency [13].

The travel frequency of the Sonosewu residents in one week is presented in Table 1. From November 30 to December 6, 2020, Sonosewu residents tended to travel with high frequency (43\%), which is between 6 to 7 times a week. As many as $35 \%$ of the population traveled in low frequency, namely not traveling or 0 times to 2 trips a week, with details of 113 people.

Table 1. Travel frequency in Sonosewu.

\begin{tabular}{|c|c|c|}
\hline $\begin{array}{c}\text { Travel Frequency } \\
\text { in a Week }\end{array}$ & Classification & Population \\
\hline $0-2$ & Low & 113 \\
\hline $3-5$ & Moderate & 74 \\
\hline $6-7$ & High & 141 \\
\hline
\end{tabular}

The population of Sonosewu mostly traveled on weekdays, and on weekends tended to be less (Table 2).

Table 2. The number of daily trips during COVID-19 pandemic.

\begin{tabular}{|c|c|}
\hline Day and Date & Number of trips \\
\hline Monday, 2020-11-30 & 205 \\
\hline Tuesday, 2020-12-01 & 209 \\
\hline Wednesday, 2020-12-02 & 190 \\
\hline Thursday, 2020-12-03 & 205 \\
\hline Friday, 2020-12-04 & 204 \\
\hline Saturday, 2020-12-05 & 176 \\
\hline Sunday, 2020-12-06 & 146 \\
\hline
\end{tabular}

\subsection{Travel purpose}

The travel of the population was mostly carried out for work, as shown in Figure 3. Accumulatively, the largest proportion of residence-based travel destinations for people of Sonosewu was travel to work (63\%), followed by destinations to shopping $(19 \%)$, social interests $(16 \%)$, school or campus $(3 \%)$, and the lowest was for recreation $(2 \%)$.

The findings in this study are different from Tamin's study, which stated that one of the main purposes of travel is to educational places [14]. The findings of this study prove that the purpose of traveling to those places was not the main activity. This was because educational activities were carried out online during the COVID-19 pandemic. Trips to education (i.e., to school or campus) made by the residents of Sonosewu amounted to 35 trips or $3 \%$ of the total trips made mostly for practical activities. These activities can be carried out by the results of adjustments to the Joint Decree of the 4 Ministers regarding the Guidelines for Implementation of Learning [15], where the implementation continues to apply the health protocol.

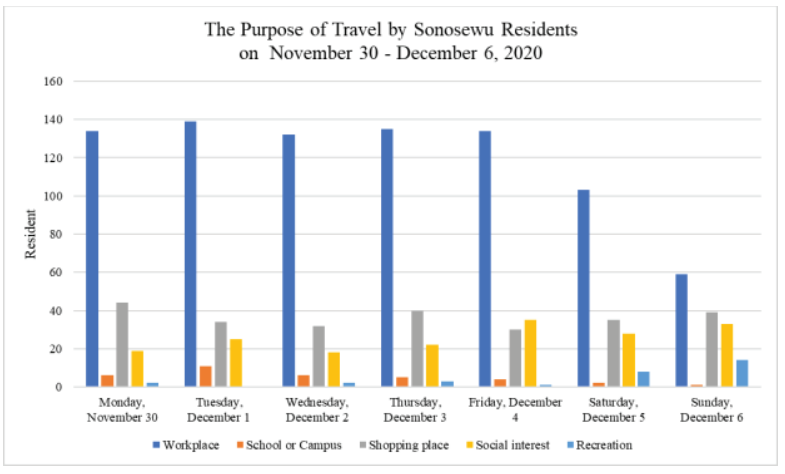

Fig. 3. Purpose of daily population travel.

The purpose of work travel was difficult to control in times of pandemic. The policies set by the government for work from home could not be applied entirely to all sectors, especially informal workers [16]. The characteristics of the residents of Sonosewu, where most of the population work as laborers, traders, and private employees, caused the application of 'work from home' not implemented. This condition occurred due to the pressure to fulfill basic needs during the pandemic.

\subsection{Location of travel destination}

The distribution of destinations for residents to travel varies widely and can be determined by several factors. Based on Figure 4, the destination locations for one week of travel during the COVID-19 pandemic to Bantul Regency and Yogyakarta City were the same, namely 520 trips each, then 255 trips to Sleman Regency, and the rest to other regions, such as Kulon Progo, Magelang, Solo, Kebumen, Lombok, Madiun, Denpasar, Gunungkidul, and Tasikmalaya [17].

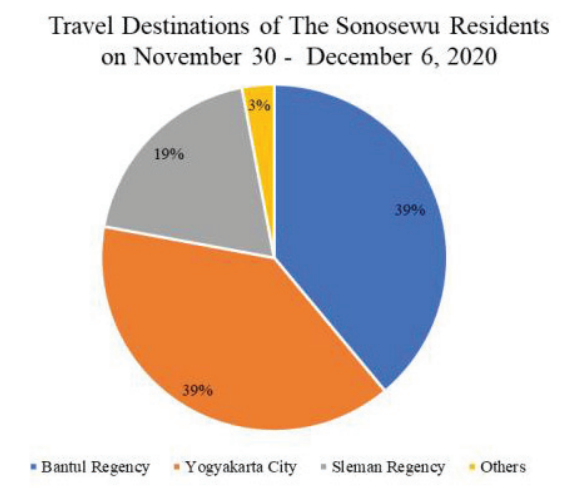

Fig. 4. Travel destinations during COVID-19 pandemic. 
Table 3. Number of daily trips.

\begin{tabular}{|c|c|c|c|c|c|}
\hline \multirow{2}{*}{ Destination Places } & \multicolumn{5}{|c|}{ Location } \\
\cline { 2 - 6 } & Sonosewu & $\begin{array}{c}\text { Bantul Regency (other } \\
\text { than Sonosewu) }\end{array}$ & Yogyakarta City & Sleman Regency & Others \\
\hline Workplace & 135 & 167 & 309 & 207 & 18 \\
\hline School or campus & 1 & 19 & 10 & 5 & 0 \\
\hline Shopping place & 69 & 32 & 126 & 25 & 2 \\
\hline Social interest & 54 & 31 & 65 & 16 & 14 \\
\hline Recreation & 1 & 11 & 10 & 2 & 6 \\
\hline Total & $\mathbf{2 6 0}$ & $\mathbf{2 6 0}$ & $\mathbf{5 2 0}$ & $\mathbf{2 5 5}$ & $\mathbf{4 0}$ \\
\hline
\end{tabular}

Given the high number of trips, it can be said that Yogyakarta City and Bantul Regency have been able to meet the living needs of the people of Sonosewu. The high number of people traveling to Yogyakarta City is due to high accessibility. The population mobility will tend to increase along with the short distance [18]. However, in the aspect of potential characteristics between Bantul Regency and Yogyakarta City, it is certainly different, including the availability of socioeconomic facilities that encourage travel.

Based on Table 3, the purpose of trips to work and shopping to Yogyakarta City was higher than in Sonosewu itself or in other hamlets in Bantul Regency. The city of Yogyakarta is known as a center of economic activity, trade and services, and government services so that it provides high job opportunities. Also, one of the destinations for residents to travel to shopping in Yogyakarta City is the Pasar Legi. Christaller in the central place theory argues that residents will look for the closest, inexpensive and accessible place to fulfill their needs to meet their needs [19]. This is following the characteristics of Pasar Legi, which is relatively close to Sonosewu and has a cheaper price. On the other hand, the purpose of the trip to the Bantul Regency is higher than Yogyakarta City, namely for recreational purposes and social interests. There are many recreational purposes in Bantul Regency apart from Sonosewu Hamlet, including for tourism purposes on the South Coast.

The aspect of population travel is one of the limited aspects during the COVID-19 pandemic. Overall, it is known that the residents of Sonosewu during the COVID-19 pandemic had a relatively high frequency of travel. This phenomenon does not mean that people are ignoring instructions from the government to stay at home. Despite the high frequency, people traveled for important purposes, such as workplaces and shopping places. Aspects of social activities that have also become the government's spotlight during the COVID19 pandemic can be described through travel with the aim of social interests. Based on the results, it is known that there were quite a lot of trips for social purposes but the distance to the destination is relatively close, namely in Sonosewu Hamlet and other areas in Bantul Regency.

\section{Conclusion}

During the COVID-19 pandemic, the people of Sonosewu tended to have a high frequency of travel, namely 6 to 7 times a week from November 30 to December 6, 2020. Most of the travel destinations during the COVID-19 pandemic were to go to work $(63 \%)$ and shopping places (19\%). The location of the destination of the Sonosewu residents' travel to Yogyakarta City was as many as those made to Bantul Regency, which is 520 times.

This paper is part of an undergraduate thesis written by the first author under the guidance of the second author. The author would like to thank the respondents in Sonosewu, Bantul Regency who were willing to fill out the questionnaire in this study.

\section{References}

1. Muhlisin, Dinamika Permukiman 2, 73-82 (2009)

2. J. de D. Ortuzar, L.G. Willumsen, Modelling Transport (4th Edition) (John Wiley \& Sons, United Kingdom, 2011)

3. A. Nugroho, Hubungan antara karakteristik sosio ekonomi demografi dan karakteristik perjalanan dengan pemilihan moda untuk maksud bekerja (Studi kasus: Kelurahan Cijaura, Kelurahan Margasari dan Kelurahan Manjahlega), Thesis (Universitas Komputer Indonesia, Bandung, 2019)

4. WHO, Pertanyaan dan jawaban terkait Coronavirus, URL:

https://www.who.int/indonesia/news/novelcoronavirus/qa/qa-for-public. (2021)

5. H. Romdiati, COVID-19 Mengubah mobilitas penduduk, URL:

http://kependudukan.lipi.go.id/en/berita/53mencatatcovid19/893-covid-19-mengubah-polamobilitas-penduduk. (2020)

6. Dinas Kesehatan Kabupaten Bantul, Zonasi risiko COVID-19 menurut kecamatan berdasarkan data 
dari 1-14 September 2020 ke Kabupaten Bantul, URL: https://corona.bantulkab.go.id/. (2020)

7. Pemerintah Kabupaten Bantul, Implementasi sektor pada zonasi risiko COVID-19, URL: https://corona.bantulkab.go.id/. (2020)

8. Google, COVID-19 community mobillity reports, URL: https:/www.google.com/covid19/mobility/. (2020)

9. OCHA, Average daily reduction in people's movement range from 1 Mar 2020 - 5 July 2020, URL: https://data.humdata.org/dataset/movementrange-maps. (2020)

10. Sugiyono, Metode penelitian pendidikan (pendekatan kuantitatif, kualitatif, dan R\&D) (Penerbit Alfabeta, Bandung, 2017)

11. R. Nuraini, Kasus Covid-19 pertama, masyarakat jangan panik, URL:

https://indonesia.go.id/narasi/indonesia-dalamangka/ekonomi/kasus-covid-19-pertamamasyarakat-jangan-panik. (2020)

12. H. S. Badr, H. Du, M. Marshall, E. Dong, M. M. Squire, L. M. Gardner, Lancet Infect. Dis. 20, 1247-1254 (2020)

13. J. De Vos, Transportation Research Interdisciplinary Perspectives 5, 1-3 (2020)

14. O.Z. Tamin, Perencanaan dan Pemodelan Transportasi (2th ed.) (Penerbit ITB, Bandung, 2000)

15. Kementerian Pendidikan dan Kebudayaan Republik Indonesia, Penyesuaian keputusan bersama empat menteri tentang panduan pembelajaran di masa pandemi COVID-19, URL: https:/www.kemdikbud.go.id/main/blog/2020/08/ penyesuaian-keputusan-bersama-empat-menteritentang-panduan-pembelajaran-di-masa-pandemicovid19. (2020)

16. A. J. Pitoyo, B. Aditya, I. Amri, E3S Web of Conferences 200, 03014 (2020)

17. D. I. Santi, Hubungan persepsi penduduk tentang bahaya pandemi COVID-19 dengan frekuensi perjalanan penduduk Dusun Sonosewu selama satu minggu, Thesis draft (unpublished)

18. I. B. Mantra, Mobilitas penduduk sirkuler dari desa ke kota di Indonesia (Pusat Penelitian Kependudukan Universitas Gadjah Mada, Yogyakarta, 1999)

19. R. A. Medina, Pola spasial pemilihan lokasi belanja kebutuhan primer penduduk Kecamatan Bogor Tengah, in 8th Industrial Research Workshop and National Seminar, 527-535 (2017) 